\title{
Combination evaluation of some Algerian medicinal plant extracts in association with antibiotics
}

\author{
Mohamed Senouci Bereksi ${ }^{1 *}$, Hafida Hassaïne ${ }^{2}$, Djamel Eddine Abdelouahid ${ }^{2}$ \\ ${ }^{1}$ Natural Products Research Laboratory (LAPRONA), Department of Biology, University of Tlemcen, 13000 Tlemcen, Algeria. \\ ${ }^{2}$ Laboratory of Applied Microbiology in Food, Biomedical and Environment (LAMAABE), Department of Biology, University of Tlemcen, 13000 \\ Tlemcen, Algeria.
}

\begin{tabular}{|c|c|}
\hline ARTICLE INFO & ABSTRACT \\
\hline Article history: & \multirow{9}{*}{$\begin{array}{l}\text { In vitro antibacterial activity of hydromethanolic extracts of nine Algerian medicinal plants were evaluated } \\
\text { alone and in combination with five antibiotics against six Gram-positive and Gram-negative pathogenic } \\
\text { bacteria: Staphylococcus aureus, Enterococcus faecalis, Escherichia coli, Enterobacter cloacae, Klebsiella } \\
\text { pneumoniae and Pseudomonas aeruginosa, using well diffusion method. The extracts of plant tested, with the } \\
\text { exception of Cassia angustifolia, Nigella sativa and Zingiber officinale, showed different levels of antibacterial } \\
\text { activities against most pathogens with diameters varying from } 06.0 \text { to } 25.0 \mathrm{~mm} \text {, especially against } S \text {. aureus. } \\
\text { Combinations of plant extracts and antibiotics showed different synergistic effects resulting in increased areas of } \\
\text { inhibition of some antibiotics combined with plant extracts, including those presented weak antibacterial } \\
\text { activity. The tested extracts could be used in combination therapy as a source of resistance modifying agents for } \\
\text { the treatment of infections caused by pathogenic bacteria. }\end{array}$} \\
\hline Received on: $17 / 01 / 2017$ & \\
\hline Accepted on: 02/03/2017 & \\
\hline Available online: $30 / 05 / 2017$ & \\
\hline Key words: & \\
\hline Antibacterial activity, & \\
\hline Hydromethanolic extracts, & \\
\hline Synergistic effects, Anti- & \\
\hline $\begin{array}{l}\text { microbial agents, Well } \\
\text { diffusion method. }\end{array}$ & \\
\hline
\end{tabular}

\section{INTRODUCTION}

One of the central themes of success in human therapeutics in the 20th century was the discovery and development of antibiotics and antibacterial agents, for the treatment of bacterial infections. A huge array of antibacterial agents has been introduced and antibiotics can be used effectively to treat major infectious diseases (Wood, 1990). However, the usage of antibiotics and antibacterial chemotherapeutics is becoming more and more restricted, because bacteria is capable of developing resistance to antibiotics soon after their introduction and most antibiotics have side effects. Therefore, it becomes essential to search for newer drugs

* Corresponding Author

Mohamed Senouci Bereksi, Mailing address: Natural Products Research Laboratory (LAPRONA), Department of Biology, University of Tlemcen, 13000 Tlemcen, Algeria. Tel.: +213-793-282-503

Email: sbereksi_mohamed @yahoo.fr with lesser rate of resistance development and lesser toxicity (Okeke et al., 2005).

Phytomedicines derived from plants have shown great promise in the treatment of intractable infectious diseases including viral infections (Cowan, 1999). Single and poly herbal preparations have been used numerously throughout history for the treatment of various diseases (Abu-Shanab et al., 2004). In rational drug therapy, the concurrent administration of two or more drugs is often essential and sometimes mandatory in order to achieve the desired therapeutic goal or to treat co-existing diseases (Levinson and Jawetz, 2002).

Many researchers have studied experimentally the synergistic effect resulting from the combination of antibiotics with different plant extracts (Aburjai et al., 2001; Aqil et al., 2005; Olajuyigbe and Afolayan, 2012). Indeed, this combination therefore allowed reducing bacterial resistance to drugs (Abascal and Yarnell, 2002). 
Thousands of species of wild herbs growing in Algeria and whose medicinal properties have been appreciated for millennia by the inhabitants belong to the most modest and domestic plants, containing substances of preventive and curative diseases (Belouad, 2001). Some Algerian plants exhibit significant potency against human bacteria (Mezouar et al., 2014; Selaadji et al., 2014), but few of them have been devoted to the study of combined effects between plants and chemical antimicrobials (Ghellai et al., 2014).

The aim of this study is to evaluate in vitro antibacterial activities of hydromethanolic extracts from nine Algerian medicinal plants and to study the possible synergistic effect of the combination of these extracts with some antibiotics against six standard bacterial strains by using the well diffusion method.

\section{MATERIAL AND METHODS}

\section{Plant materials}

Samples of Cistus monspeliensis (aerial part), Punica granatum (fruit peels) and Withania frutescens (leaves) were collected from Tlemcen (West of Algeria) and Rhus tripartita (aerial part) was collected in the region of Bechar (South of Algeria), in March 2013. They were identified in the Laboratory of Natural Products, Department of Biology, University of Tlemcen, Algeria. Voucher specimens were deposited at the Herbarium of the Laboratory.

The plants were dried at room temperature for two weeks. While Berberis vulgaris (root bark), Cassia angustifolia (leaves), Cinnamomum cassia (peels), Nigella sativa (seeds) and Zingiber officinale (rhizome) were purchased from local market in Tlemcen, Algeria in the same period.

\section{Preparation of plant extracts}

Air dried material of each species was ground and submitted for extraction. $10 \mathrm{~g}$ of the dry plant powder of each plant was macerated with $100 \mathrm{ml}$ of methanol/water $(80: 20$, v/v) overnight at room temperature under constant shaking. The extracts were then filtered and concentrated under reduced pressure at $45{ }^{\circ} \mathrm{C}$ using rotary evaporator (Hahnvapor, Hahn Shin Scientific, South Korea).

Then, the dry residues were dissolved in Dimethylsulfoxid (DMSO) to a final concentration of $100 \mathrm{mg} / \mathrm{ml}$ and filtered by $0.45 \mu \mathrm{m}$ Millipore filters for sterilization before used.

\section{Bacterial strains}

Six bacterial strains were used in this study, Staphylococcus aureus (ATCC 29213), Enterococcus faecalis (ATCC 29212), Escherichia coli (ATCC 25922), Entrobacter cloacae (ATCC 13047), Klebsiella pneumoniae (ATCC 700603) and Pseudomonas aeruginosa (ATCC 27853). Usually, these strains are the most common Gram positive and Gram negative bacteria found in nosocomial infections (Kaoutar et al., 2004).
Bacterial strains were grown on nutrient agar slants for $24 \mathrm{~h}$ at 37 ${ }^{\circ} \mathrm{C}$ then used in the experiments.

\section{Antibiotics}

Plant extracts of the current study were evaluated for synergism assay with five antibiotics (Amoxicillin, Ceftazidim, Ceftriaxon, Cefotaxim and Cefazolin) which were diluted to a final concentration of $1000 \mu \mathrm{g} / \mathrm{ml}$.

\section{Determination of antibacterial activity and synergistic effect}

Antibacterial activity was measured by well diffusion method according to the Clinical and Laboratory Standards Institute (formerly National Committee for Clinical Laboratory Standard) (NCCLS, 1993). Briefly, plates containing approximately 25-30 $\mathrm{ml}$ of Mueller Hinton agar medium were inoculated using a cotton swab with a 18-24 h old culture of the bacterial strains. Wells (6 mm diameter) were punched in the agar and filled with $30 \mu \mathrm{l}$ of plant extracts or antibiotics. The plates were incubated at $37^{\circ} \mathrm{C}$ for $18-24 \mathrm{~h}$. The antibacterial activity was assessed by measuring the inhibition zone diameter $(\mathrm{mm})$ around the well.

Synergism effect was evaluated using the previous method. The wells were filled with $30 \mu \mathrm{l}$ of antibiotic and $30 \mu \mathrm{l}$ of plant extract (Adwan et al., 2008). An increase in growth inhibition zone indicates a synergistic effect (Ahmed et al., 2007).

\section{RESULTS AND DISCUSSION}

Antibacterial activities of hydromethanolic extracts of nine medicinal plants and their combinations with antibiotics were assayed in vitro by the well diffusion method against six standard Gram-positive and Gram-negative pathogenic bacteria (Tables 1, $2,3,4,5,6)$. It can be noted that most of antibiotics showed different levels of antibacterial activity against different bacterial strains. All the tested bacteria were more or less sensitive to the plant extracts. The plant extracts, except those of Cassia angustifolia and Zingiber officinale, showed the most important antibacterial activity against $S$. aureus with diameters of the zones of inhibition varying from 09.0 to $25.0 \mathrm{~mm}$. We can note that this activity is much more pronounced by Berberis vulgaris, Cinnamomum cassia, Cistus monspeliensis, Punica granatum and Withania frutescens with diameters of the zones of 25.0, 15.0, 18.0, 22.0 and $17.0 \mathrm{~mm}$ respectively (Table 1 ). This high activity may be due to the composition of these extracts with compounds which may be responsible for this activity. Indeed, plants are rich in a variety of phytochemicals including tannins, terpenoids, alkaloids, and flavonoids which have been found in vitro to have antimicrobial properties (Dorman and Deans, 2000; Talib and Mahasneh, 2010).

For the other bacterial species, only the extracts of $C$. cassia, $C$. monspeliensis and $P$. granatum showed a moderate activity with diameters varying from 09.0 to $11.0 \mathrm{~mm}$ (Tables 2,3 , 4, 5, 6). However, these plants gave appreciable activity (diameters of $12.0,14.0$ and $15.0 \mathrm{~mm}$ respectively) against 
Table 1: Antibacterial activity of plant extracts and synergistic effects with antibiotics on Staphylococcus aureus (mm).

\begin{tabular}{|c|c|c|c|c|c|c|c|}
\hline & \multirow{3}{*}{ Plant } & \multirow{3}{*}{ Extracts alone } & \multicolumn{5}{|c|}{ Antibiotics (alone/combined with extracts) } \\
\hline & & & AMX & CAZ & CRO & CTX & $\mathbf{C Z}$ \\
\hline & & & 46.0 & 24.0 & 25.0 & 30.0 & 41.0 \\
\hline$>$ & Berberis vulgaris & 25.0 & $44.0 \mathrm{~A}$ & $25.0 \mathrm{I}$ & $26.0 \mathrm{I}$ & $34.0 \mathrm{~S}$ & $38.0 \mathrm{~A}$ \\
\hline$>$ & Cassia angustifolia & - & $46.0 \mathrm{I}$ & $22.0 \mathrm{~A}$ & $26.0 \mathrm{I}$ & $32.0 \mathrm{~S}$ & $40.0 \mathrm{~A}$ \\
\hline$>$ & Cinnamoтит cassia & 15.0 & $42.0 \mathrm{~A}$ & $21.0 \mathrm{~A}$ & $26.0 \mathrm{I}$ & $30.0 \mathrm{I}$ & $36.0 \mathrm{~A}$ \\
\hline$>$ & Cistus monspeliensis & 18.0 & $46.0 \mathrm{I}$ & $21.0 \mathrm{~A}$ & $28.0 \mathrm{~S}$ & $32.0 \mathrm{~S}$ & $37.0 \mathrm{~A}$ \\
\hline$>$ & Nigella sativa & 09.0 & $40.0 \mathrm{~A}$ & $21.0 \mathrm{~A}$ & $25.0 \mathrm{~A}$ & $31.0 \mathrm{I}$ & $37.0 \mathrm{~A}$ \\
\hline$>$ & Punica granatum & 22.0 & $46.0 \mathrm{I}$ & $24.0 \mathrm{I}$ & $28.0 \mathrm{~S}$ & $32.0 \mathrm{~S}$ & $40.0 \mathrm{I}$ \\
\hline$>$ & Rhus tripartita & 12.0 & $40.0 \mathrm{~A}$ & $22.0 \mathrm{~A}$ & $22.0 \mathrm{~A}$ & $28.0 \mathrm{~A}$ & $43.0 \mathrm{~S}$ \\
\hline$>$ & Withania frutescens & 17.0 & $48.0 \mathrm{~S}$ & $22.0 \mathrm{~A}$ & $23.0 \mathrm{~A}$ & $29.0 \mathrm{~A}$ & $45.0 \mathrm{~S}$ \\
\hline$>$ & Zingiber officinale & - & $40.0 \mathrm{~A}$ & $22.0 \mathrm{~A}$ & $24.0 \mathrm{~A}$ & $31.0 \mathrm{I}$ & $43.0 \mathrm{~S}$ \\
\hline
\end{tabular}

$-:$ No inhibition zone observed, AMX : Amoxicillin, CAZ : Ceftazidim, CRO : Ceftriaxon, CTX : Céfotaxim, CZ : Céfazolin, S : Synergy, A : Antagonism, I : Indifference.

Table 2: Antibacterial activity of plant extracts and synergistic effects with antibiotics on Enterococcus faecalis (mm).

\begin{tabular}{|c|c|c|c|c|c|c|c|}
\hline & \multirow{3}{*}{ Plant } & \multirow{3}{*}{$\begin{array}{l}\text { Extracts } \\
\text { alone }\end{array}$} & \multicolumn{5}{|c|}{ Antibiotics (alone/combined with extracts) } \\
\hline & & & AMX & CAZ & CRO & CTX & $\mathbf{C Z}$ \\
\hline & & & 13.0 & 40.0 & 39.0 & 38.0 & - \\
\hline$>$ & Berberis vulgaris & - & $12.0 \mathrm{~A}$ & $42.0 \mathrm{~S}$ & $36.0 \mathrm{~A}$ & $36.0 \mathrm{~A}$ & - \\
\hline$>$ & Cassia angustifolia & - & $13.0 \mathrm{I}$ & $39.0 \mathrm{~A}$ & $36.0 \mathrm{~A}$ & $36.0 \mathrm{~A}$ & - \\
\hline$>$ & Cinnamoтит cassia & 12.0 & $12.0 \mathrm{~A}$ & $39.0 \mathrm{~A}$ & $36.0 \mathrm{~A}$ & $36.0 \mathrm{~A}$ & $11.0 \mathrm{~A}$ \\
\hline$>$ & Cistus monspeliensis & 09.0 & $10.0 \mathrm{~A}$ & $38.0 \mathrm{~A}$ & $35.0 \mathrm{~A}$ & $36.0 \mathrm{~A}$ & $09.0 \mathrm{I}$ \\
\hline$>$ & Nigella sativa & - & $16.0 \mathrm{~S}$ & $39.0 \mathrm{~A}$ & $36.0 \mathrm{~A}$ & $36.0 \mathrm{~A}$ & - \\
\hline$>$ & Punica granatum & 11.0 & $11.0 \mathrm{~A}$ & $38.0 \mathrm{~A}$ & $36.0 \mathrm{~A}$ & $37.0 \mathrm{~A}$ & $10.0 \mathrm{~A}$ \\
\hline$>$ & Rhus tripartita & - & $12.0 \mathrm{I}$ & $36.0 \mathrm{~A}$ & $34.0 \mathrm{~A}$ & $35.0 \mathrm{~A}$ & - \\
\hline$>$ & Withania frutescens & - & $12.0 \mathrm{I}$ & $42.0 \mathrm{~S}$ & $45.0 \mathrm{~S}$ & $35.0 \mathrm{~A}$ & - \\
\hline$>$ & Zingiber officinale & - & $13.0 \mathrm{I}$ & $39.0 \mathrm{~A}$ & $37.0 \mathrm{~A}$ & $36.0 \mathrm{~A}$ & - \\
\hline
\end{tabular}

- : No inhibition zone observed, AMX : Amoxicillin, CAZ : Ceftazidim, CRO : Ceftriaxon, CTX : Céfotaxim, CZ : Céfazolin, S : Synergy, A : Antagonism, I : Indifference.

Table 3: Antibacterial activity of plant extracts and synergistic effects with antibiotics on Escherichia coli (mm).

\begin{tabular}{|c|c|c|c|c|c|c|c|}
\hline & \multirow{3}{*}{ Plant } & \multirow{3}{*}{$\begin{array}{c}\text { Extracts } \\
\text { alone }\end{array}$} & \multicolumn{5}{|c|}{ Antibiotics (alone/combined with extracts) } \\
\hline & & & AMX & CAZ & CRO & CTX & $\mathbf{C Z}$ \\
\hline & & & 20.0 & 33.0 & 33.0 & 36.0 & 24.0 \\
\hline 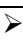 & Berberis vulgaris & - & $17.0 \mathrm{~A}$ & $30.0 \mathrm{~A}$ & $33.0 \mathrm{I}$ & $35.0 \mathrm{~A}$ & $21.0 \mathrm{~A}$ \\
\hline$>$ & Cassia angustifolia & - & $16.0 \mathrm{~A}$ & $30.0 \mathrm{~A}$ & $32.0 \mathrm{~A}$ & $37.0 \mathrm{I}$ & $21.0 \mathrm{~A}$ \\
\hline$>$ & Cinnamomum cassia & 11.0 & $18.0 \mathrm{~A}$ & $30.0 \mathrm{~A}$ & $34.0 \mathrm{I}$ & $38.0 \mathrm{~S}$ & $22.0 \mathrm{~A}$ \\
\hline$>$ & Cistus monspeliensis & 11.0 & $11.0 \mathrm{~A}$ & $30.0 \mathrm{~A}$ & $32.0 \mathrm{~A}$ & $36.0 \mathrm{I}$ & $22.0 \mathrm{~A}$ \\
\hline$>$ & Nigella sativa & - & $17.0 \mathrm{~A}$ & $31.0 \mathrm{~A}$ & $32.0 \mathrm{~A}$ & $36.0 \mathrm{I}$ & $21.0 \mathrm{~A}$ \\
\hline$>$ & Punica granatum & 10.0 & $10.0 \mathrm{~A}$ & $32.0 \mathrm{~A}$ & $33.0 \mathrm{I}$ & $40.0 \mathrm{~S}$ & $21.0 \mathrm{~A}$ \\
\hline$>$ & Rhus tripartita & 09.0 & $12.0 \mathrm{~A}$ & $32.0 \mathrm{~A}$ & $31.0 \mathrm{~A}$ & $35.0 \mathrm{~A}$ & $24.0 \mathrm{I}$ \\
\hline$>$ & Withania frutescens & - & $20.0 \mathrm{I}$ & $32.0 \mathrm{~A}$ & $31.0 \mathrm{~A}$ & $34.0 \mathrm{~A}$ & $24.0 \mathrm{I}$ \\
\hline$>$ & Zingiber officinale & - & $19.0 \mathrm{~A}$ & $32.0 \mathrm{~A}$ & $32.0 \mathrm{~A}$ & $35.0 \mathrm{~A}$ & $24.0 \mathrm{I}$ \\
\hline
\end{tabular}

- : No inhibition zone observed, AMX : Amoxicillin, CAZ : Ceftazidim, CRO : Ceftriaxon, CTX : Céfotaxim, CZ : Céfazolin, S : Synergy, A : Antagonism, I : Indifference.

$P$. aeruginosa, which is known for it increased resistance to various antimicrobial agents. According to the literature, the difference in sensitivity between Gram positive and Gram negative bacteria can be ascribed to morphological differences between these microorganisms, above all to differences in the permeability of the cell wall (Nastro et al., 2000). Antimicrobial combinations are used for a number of reasons: expansion of antimicrobial spectrum, minimization of drug toxicity, minimization of antimicrobial resistance, and antimicrobial synergism (Verma, 2007). Combinations between the extracts of the studied plants and the antibiotics tested showed different effects of synergy or indifference, while other interactions presented an antagonism against the different bacterial strains tested. For the $S$. aureus strain, a synergistic effect was observed between cefotaxim and extracts of $B$. vulgaris and $C$. angustifolia, and also between cefotaxim and ceftriaxon with the extracts of $C$. monspeliensis and $P$. granatum. Simultaneously, cefazolin presented a synergy with $R$. tripartita, W. frutescens and Z. officinale extracts, and also amoxicillin when combined with $W$. frutescens (Table 1). From Table 2, we note a synergism between amoxicillin, ceftazidim and ceftriaxon when they were combined with $B$. vulgatis, $N$. sativa and $W$. frutescens respectively, against $E$. faecalis. In parallel, $C$. cassia and $P$. granatum showed synergistic interactions against $E$. coli when combined with cefotaxim (Table 3).

A synergistic effect was also observed in E. cloacae (Table 4) when combinations between amoxicillin and cefazolin and extracts of $C$. cassia, $C$. monspeliensis and $R$. tripartita were applied. No synergistic effect was detected in the combination of all plant extracts with the antibiotics tested against $K$. pneumoniae. However, we note an interaction leading to a synergistic effect between amoxicillin and the extract of $C$. cassia against $P$. aeruginosa (Tables 5, 6). 
Table 4: Antibacterial activity of plant extracts and synergistic effects with antibiotics on Enterobacter cloacae (mm)

\begin{tabular}{|c|c|c|c|c|c|c|c|}
\hline & \multirow[b]{2}{*}{ Plant } & \multirow{2}{*}{$\begin{array}{l}\text { Extracts } \\
\text { alone }\end{array}$} & \multicolumn{5}{|c|}{ Antibiotics (alone/combined with extracts) } \\
\hline & & & AMX & CAZ & CRO & CTX & $\mathbf{C Z}$ \\
\hline$>$ & Berberis vulgaris & - & - & $30.0 \mathrm{~A}$ & $31.0 \mathrm{~A}$ & $36.0 \mathrm{I}$ & - \\
\hline$>$ & Cassia angustifolia & - & - & $30.0 \mathrm{~A}$ & $32.0 \mathrm{I}$ & $33.0 \mathrm{~A}$ & - \\
\hline$>$ & Cinnamomum cassia & 09.0 & $12.0 \mathrm{~S}$ & $30.0 \mathrm{~A}$ & $32.0 \mathrm{I}$ & $34.0 \mathrm{~A}$ & $16.0 \mathrm{~S}$ \\
\hline$>$ & Cistus monspeliensis & - & $09.0 \mathrm{~S}$ & $30.0 \mathrm{~A}$ & $32.0 \mathrm{I}$ & $33.0 \mathrm{~A}$ & $10.0 \mathrm{~S}$ \\
\hline$>$ & Nigella sativa & - & - & $31.0 \mathrm{~A}$ & $31.0 \mathrm{~A}$ & $34.0 \mathrm{~A}$ & - \\
\hline$>$ & Punica granatum & 10.0 & $11.0 \mathrm{I}$ & $28.0 \mathrm{~A}$ & $28.0 \mathrm{~A}$ & $34.0 \mathrm{~A}$ & $11.0 \mathrm{I}$ \\
\hline$>$ & Rhus tripartita & - & $11.0 \mathrm{~S}$ & $31.0 \mathrm{~A}$ & $28.0 \mathrm{~A}$ & $32.0 \mathrm{~A}$ & $08.0 \mathrm{~S}$ \\
\hline$>$ & Withania frutescens & - & - & $30.0 \mathrm{~A}$ & $30.0 \mathrm{~A}$ & $32.0 \mathrm{~A}$ & - \\
\hline$>$ & Zingiber officinale & - & - & $33.0 \mathrm{I}$ & $29.0 \mathrm{~A}$ & $32.0 \mathrm{~A}$ & - \\
\hline
\end{tabular}

- : No inhibition zone observed, AMX : Amoxicillin, CAZ : Ceftazidim, CRO : Ceftriaxon, CTX : Céfotaxim, CZ : Céfazolin, S : Synergy, A : Antagonism, I : Indifference.

Table 5: Antibacterial activity of plant extracts and synergistic effects with antibiotics on Klebsiella pneumoniae (mm).

\begin{tabular}{|c|c|c|c|c|c|c|c|}
\hline \multirow{3}{*}{\multicolumn{2}{|c|}{ Plant }} & \multirow{3}{*}{$\begin{array}{c}\text { Extracts } \\
\text { alone }\end{array}$} & \multicolumn{5}{|c|}{ Antibiotics (alone/combined with extracts) } \\
\hline & & & AMX & CAZ & CRO & CTX & $\mathbf{C Z}$ \\
\hline & & & - & 22.0 & 26.0 & 30.0 & 11.0 \\
\hline$>$ & Berberis vulgaris & - & - & $21.0 \mathrm{~A}$ & $23.0 \mathrm{~A}$ & $29.0 \mathrm{~A}$ & $11.0 \mathrm{I}$ \\
\hline$>$ & Cassia angustifolia & - & - & $21.0 \mathrm{~A}$ & $24.0 \mathrm{~A}$ & $29.0 \mathrm{~A}$ & $12.0 \mathrm{I}$ \\
\hline$>$ & Cinnamomum cassia & 10.0 & $11.0 \mathrm{I}$ & $22.0 \mathrm{I}$ & $25.0 \mathrm{~A}$ & $28.0 \mathrm{~A}$ & $11.0 \mathrm{I}$ \\
\hline$>$ & Cistus monspeliensis & 10.0 & $10.0 \mathrm{I}$ & $21.0 \mathrm{~A}$ & $24.0 \mathrm{~A}$ & $28.0 \mathrm{~A}$ & $09.0 \mathrm{~A}$ \\
\hline$>$ & Nigella sativa & - & - & $21.0 \mathrm{~A}$ & $24.0 \mathrm{~A}$ & $28.0 \mathrm{~A}$ & $10.0 \mathrm{~A}$ \\
\hline$>$ & Punica granatum & 11.0 & $10.0 \mathrm{~A}$ & $20.0 \mathrm{~A}$ & $24.0 \mathrm{~A}$ & $28.0 \mathrm{~A}$ & $09.0 \mathrm{~A}$ \\
\hline$>$ & Rhus tripartita & - & - & $14.0 \mathrm{~A}$ & $25.0 \mathrm{~A}$ & $28.0 \mathrm{~A}$ & $10.0 \mathrm{~A}$ \\
\hline$>$ & Withania frutescens & - & - & $22.0 \mathrm{I}$ & $27.0 \mathrm{I}$ & $30.0 \mathrm{I}$ & $09.0 \mathrm{~A}$ \\
\hline$>$ & Zingiber officinale & - & - & $21.0 \mathrm{~A}$ & $25.0 \mathrm{~A}$ & $28.0 \mathrm{~A}$ & $11.0 \mathrm{I}$ \\
\hline
\end{tabular}


Indifference.

Table 6: Antibacterial activity of plant extracts and synergistic effects with antibiotics on Pseudomonas aeruginosa (mm).

\begin{tabular}{|c|c|c|c|c|c|c|c|}
\hline & \multirow{3}{*}{ Plant } & \multirow{3}{*}{$\begin{array}{c}\text { Extracts } \\
\text { alone }\end{array}$} & \multicolumn{5}{|c|}{ Antibiotics (alone/combined with extracts) } \\
\hline & & & AMX & CAZ & CRO & CTX & $\mathbf{C Z}$ \\
\hline & & & - & 36.0 & 28.0 & 27.0 & - \\
\hline$>$ & Berberis vulgaris & - & - & $34.0 \mathrm{~A}$ & $25.0 \mathrm{~A}$ & $25.0 \mathrm{~A}$ & - \\
\hline$>$ & Cassia angustifolia & - & - & $35.0 \mathrm{~A}$ & $24.0 \mathrm{~A}$ & $23.0 \mathrm{~A}$ & - \\
\hline$>$ & Cinnamomum cassia & 12.0 & $14.0 \mathrm{~S}$ & $33.0 \mathrm{~A}$ & $25.0 \mathrm{~A}$ & $24.0 \mathrm{~A}$ & $13.0 \mathrm{I}$ \\
\hline$>$ & Cistus monspeliensis & 14.0 & $14.0 \mathrm{I}$ & $36.0 \mathrm{I}$ & $25.0 \mathrm{~A}$ & $26.0 \mathrm{~A}$ & $12.0 \mathrm{~A}$ \\
\hline$>$ & Nigella sativa & - & - & $34.0 \mathrm{~A}$ & $22.0 \mathrm{~A}$ & $23.0 \mathrm{~A}$ & - \\
\hline$>$ & Punica granatum & 15.0 & $16.0 \mathrm{I}$ & $35.0 \mathrm{~A}$ & $24.0 \mathrm{~A}$ & $24.0 \mathrm{~A}$ & $16.0 \mathrm{I}$ \\
\hline$>$ & Rhus tripartita & - & - & $33.0 \mathrm{~A}$ & $24.0 \mathrm{~A}$ & $25.0 \mathrm{~A}$ & - \\
\hline$>$ & Withania frutescens & - & - & $33.0 \mathrm{~A}$ & $23.0 \mathrm{~A}$ & $25.0 \mathrm{~A}$ & - \\
\hline$>$ & Zingiber officinale & - & - & $34.0 \mathrm{~A}$ & $25.0 \mathrm{~A}$ & $24.0 \mathrm{~A}$ & - \\
\hline
\end{tabular}

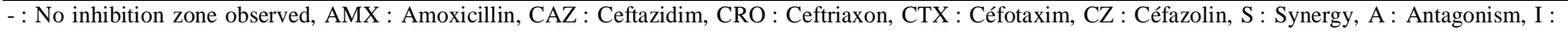
Indifference.

Our results are in agreement with previous works on combinations of antimicrobial agents with different plant extracts which reported synergistic effects against different resistant bacteria (Ahmed and Aqil, 2007; Aiyegoro et al., 2009; Horiuchi et al., 2007; Nascimento et al., 2000) and stand out as veritable sources of potential resistance modifying agents (Sibanda and Okoh, 2007). For the rest of combinations, although some of plant extracts showed weak antibacterial activity, they exhibited either indifference or antagonistic effects on different tested bacterial strains. This could be attributed to the inability of higher concentrations of plant extracts to diffuse through the agar medium. This impairment in drug diffusion is a major limitation in the evaluation of the antimicrobial effects of plant extracts using the agar diffusion method (Esimone et al., 2006). We can note that the synergism recorded here to plant extracts with weak action on different tested bacterial strains, such as $C$. angustifolia, $N$. sativa and $Z$. officinale, is an important data since they showed a synergism profile similar to that of B. vulgaris, $C$. monspeliensis and $P$. granatum extracts, considered the most active tested plant extracts in this study. Thus, certain authors suggest that the researchers should investigate the synergistic capacity of plant extracts or other natural products; independent of the antimicrobial activity they have (Betoni et al., 2006). A number of in vitro studies have reported the use of plant extracts in combination with antibiotics, showing significant reduction in the Minimum Inhibitory Concentrations of the antibiotics against some drug resistant strains, thus potentiating their antimicrobial activities (Sibanda and Okoh, 2007; Darwish and Aburjai, 2010). According to some studies, combinations of plant extracts and antibiotics using MICs have demonstrated synergistic effects compared to the indifferent effect of these extracts, including those with weak antibacterial activity, when they are studied by the well diffusion method (Adwan et al., 2010). Thus, it may be necessary to test the interaction between plant extracts tested in this study and the 
antibiotics by MIC study to assess any other synergistic effects between these plants and antibiotics, especially those with low antibacterial activity.

\section{CONCLUSION}

In the present study, antibacterial activity of different plant hydromethanolic extracts against tested strains was confirmed and the data showed that combination effects of these plant extracts with all tested antibiotics had antibacterial enhancement (synergism) against most pathogenic bacteria. These results suggest the possibility of use of these antibiotics in association with plant extracts to treat infections caused by bacterial strains often characterized by their multi-drug resistance profile. It is necessary to carry out a bioassay guided fractionation of studied plant extracts in order to isolate and identify the compounds responsible for synergistic activity with antibiotics. Elucidation of action mechanisms of these compounds must be followed by toxicity and in vivo tests to determine applicability of such compounds in combination therapy.

\section{Financial support and sponsorship: Nil.}

\section{Conflict of Interests: There are no conflicts of interest.}

\section{REFERENCES}

Abascal K, Yarnell E. Herbs and drug resistance: part 2-clinical implications of research on microbial resistance to antibiotics. Altern Complement Ther, 2002; 8: 284-290.

Aburjai T, Darwish RM, Al-Khalil S, Mahgzah A, Al-Abbdi A. Screening of antibiotic resistant inhibitors from local plant materials against two different strains of Pseudomonas aeruginosa. J. Ethnopharmacol, 2001; 76: 39-44.

Abu-Shanab B, Adwan G, Abu-Safiya D. Antibacterial activities of some plant extracts utilized in popular medicine in Palestine. Turk J Biol, 2004; 28: 99-102.

Adwan G, Mhanna M. Synergistic effects of plant extracts and antibiotics on Staphylococcus aureus strains isolated from clinical specimens. Middle East J Sci Res, 2008; 3(3): 134-139.

Adwan G, Abu-Shanab B, Adwan K. Antibacterial activities of some plant extracts alone and in combination with different antimicrobials against multidrug-resistant Pseudomonas aeruginosa strains. Asian Pac J Trop Med, 2010; 266-269.

Ahmad I, Aqil F. In vitro efficacy of bioactive extracts of 15 medicinal plants against ES $\beta$ L-producing multidrug-resistant enteric bacteria. Microbiol Res, 2007; 162, 264-275.

Aiyegoro OA, Afolayan AJ, Okoh AI. Synergistic interaction of Helichrysum pedunculatum leaf extracts with antibiotics against wound infection associated bacteria. Biol Res, 2009; 42: 327-338.

Aqil F, Khan MSA, Owais M, Ahmad I. Effect of certain bioactive plant extracts on clinical isolates of $\beta$-lactamase producing methicilin resistant Staphylococcus aureus. J. Basic. Microbiol, 2005; 45: 106-114.

Beloued A. 2001. Plantes médicinales d'Algérie (Medicinal plants from Algeria). Algiers, Algeria: Office des Publications Universitaires.

Betoni JE, Mantovani RP, Barbosa LN, Di Stasi LC, Fernandes Junior A. Synergism between plant extract and antimicrobial drugs used on Staphylococcus aureus diseases. Mem Inst Oswaldo Cruz, 2006; 101(4): 387-390.

Cowan MM. Plant Products as Antimicrobial Agents. Clin Microbiol Rev, 1999; 12: 564-582.
Dorman HJ, Deans SG. Antimicrobial agents from plants: antibacterial activity of plant volatile oils. J Appl Microbiol, 2000; 88: 308-316.

Darwish RM, Aburjai TA. Effect of ethnomedicinal plants used in folklore medicine in Jordan as antibiotic resistant inhibitors on Escherichia coli. BMC Complement Altern Med, 2010; 10: 9.

Esimone CO, Iroha IR, Ibezim EC, Okeh CO, Okpana EM. In vitro evaluation of the interaction between tea extracts and penicillin $\mathrm{G}$ against staphylococcus aureus. Afr. J. Biotechnol, 2006; 5: 1082-1086.

Ghellai L, Hassaine H, Klouche Khelil N, Nas F, Aissaoui N, Hoceini A, Ziouane S, Zing W. Antibacterial efficacy of essential oils of three aromatic plants in combination with povidone-iodine against Staphylococcus aureus grown in biofilm cultures. J App Pharm Sci, 2014; 4 (07): 088-093

Horiuchi K, Shiota S, Kuroda T, Hatano T, Yoshida T, Tsuchiya T. Potentiation of antimicrobial activity of aminoglycosides by carnosol from Salvia officinalis. Biol Pharm Bull, 2007; 30: 287-290.

Kaoutar B, Joly C, L'Hériteau F, Barbut F, Robert J, Denis M, Espinasse F, Merrer J, Doit C, Costa Y, Daumal F, Blanchard HS, Eveillard M, Botherel A-H, Brücker G, Astagneau P. Nosocomial infections and hospital mortality: a multicentre epidemiological study. J Hosp Infect, 2004; 58: 268-275.

Levinson W, Jawetz E. 2002. Medical microbiology and immunology: Examination and board review. International ed. (7th), Lange Medical Books/McGraw-Hill, New York.

Mezouar D, Lahfa FB, Abdelouahid DE, Adida H, Rahmoun NM, Boucherit-Otmani Z. Activité antimicrobienne d'extraits d'écorce de racines de Berberis vulgaris. Phytothérapie, 2014; 12(6): 380-385.

National Committee for Clinical Laboratory Standards (NCCLS), 1993. Performance Standards for Antimicrobial Disc Suspectibility Tests. Approved Standard NCCLS Publication, Villanova, PA, USA, M2-A5.

Nascimento GGF, Locatelli J, Freitas PC, Silva GL. Antibacterial activity of plant extracts and phytochemicals on antibioticresistant bacteria. Braz J Microbiol, 2000; 31: 247-256.

Nostro MP, Germanó V, D’Angelo A, Marino Cannatelli MA. Extraction methods and bioautography for evaluation of medical plant antimicrobial activity. Lett Appl Microbiol, 2000; 30, 379-384.

Okeke I, Laxminarayan R, Bhutta Z, Duse A, Jenkins P, O'Brien T. Antimicrobial resistance in developing countries. Part I: recent trends and current status. Lancet Infect Dis, 2005, 5(8): 481-493.

Olajuyigbe OO, Afolayan AJ. Synergistic interactions of methanolic extract of Acacia mearnsii De Wild. with antibiotics against bacteria of clinical relevance. Int J Mol Sci, 2012; 13: 8915-32.

Seladji M, Bekhechi C, Beddou F, Dib H, Bendimerad N. Antioxidant activity and phytochemical screening of Nepeta nepetella aqueous and methanolic extracts from Algeria. J App Pharm Sci, 2014; 4 (02), 012-016.

Sibanda T, Okoh AI. The challenges of overcoming antibiotic resistance: Plant extracts as potential sources of antimicrobial and resistance modifying agents. Afr. J. Biotechnol, 2007; 6: 2886-2896.

Talib WH, Mahasneh AM. Antimicrobial, cytotoxicity and phytochemical screening of Jordanian plants used in traditional medicine. Molecules, 2010; 15: 1811-1824.

Verma P. 2007. Methods for Determining Bactericidal Activity and Antimicrobial Interactions: Synergy Testing, Time-Kill Curves, and Population Analysis. In: Schwalbe R, Steele-Moore L, Goodwin AC, ed. Antimicrobial Susceptibility Testing Protocols. New York: CRC Press, Taylor \& Françis 275-298.

Wood M. A review of antibiotics. Practitioner, 1990; 234: 10411044.

\section{How to cite this article:}

Bereksi MS, Hassaïne H, Abdelouahid DE. Combination evaluation of some Algerian medicinal plant extracts in association with antibiotics. J App Pharm Sci, 2017; 7 (05): 184-188. 